\title{
Images from the Haematologica Atlas of Hematologic Cytology: plasma cell myeloma
}

\section{Rosangela Invernizzi}

University of Pavia, Pavia, Italy

E-mail: ROSANGELA INVERNIZZI - rosangela.invernizzi@unipv.it

doi:10.3324/haematol.2021.278331

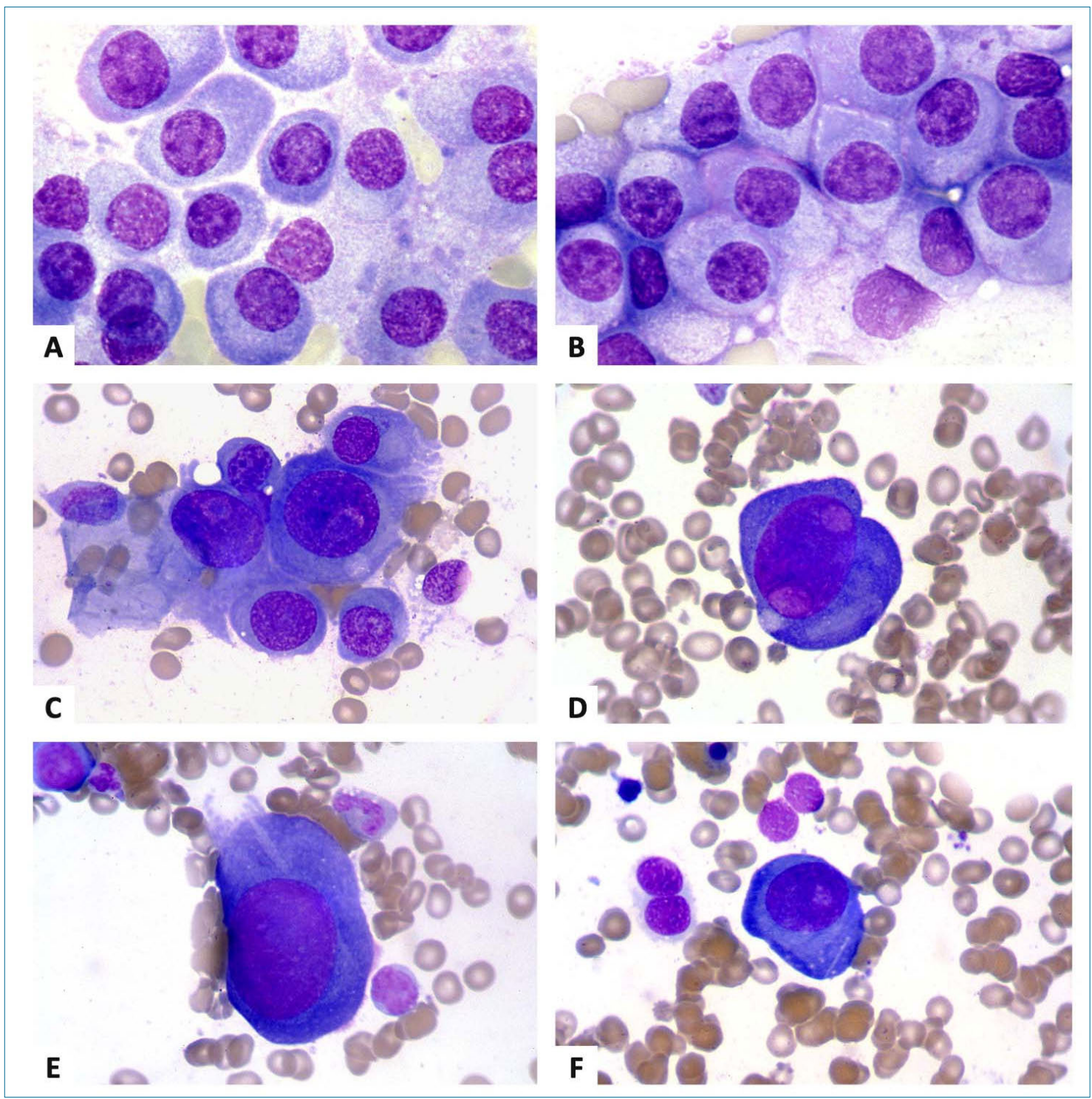

Tn plasma cell myeloma, the pleomorphism of plasma cells is mostly due to the fact that they are secretory cells and have abundant endoplasmic reticulum which may contain condensed or crystallized immunoglobulin. The Figure shows increased protein in the background with cellular debris (A); plasma cells with reticular cytoplasmic structures and pink-red periphery (center) (B); a group of plasmablasts with irregular cytoplasmic margins, cytoplasmic streamers and crystalline inclusions (C); a giant plasmablast with two macronucleoli and deeply basophilic cytoplasm with immunoglobulin accumulation in the form of amorphous substance or crystals (D). In Figure E and F, note the elongated lance-like and crystalline structures within the cytoplasm of giant plasmablasts. ${ }^{1}$

\section{References}

1. Invernizzi R. Mature B-cell neoplasms. Haematologica. 2020;105(Suppl 1):139-161. 